\title{
Rest Denied, Rest Reclaimed
}

\section{Lynne Friedli and Nina Garthwaite}

\begin{abstract}
This chapter includes an extract from a conversation between Lynne Friedli (a researcher with a special interest in mental health and social justice) and Nina Garthwaite (a founder of In The Dark, an arts organization dedicated to creative radio storytelling, who also worked for six years at a homeless hostel in London), and draws on a series of meetings with residents of a hostel, with whom they discussed welfare benefits, politics, work, rest and everything in between. Through their collaboration they became drawn to dialogue and debate as a tool of research and action.
\end{abstract}

Keywords Benefits claimants · Homelessness · Poverty · Testimony · Work

During 2015, we held a series of conversations over afternoon tea with residents and staff of the Queen Victoria Seamen's Rest (QVSR), a hostel in East London for seafarers, ex-service and homeless men, where one of us

\footnotetext{
L. Friedli $(\bowtie)$

London, United Kingdom

e-mail: lynne.friedli@btopenworld.com

N. Garthwaite

In The Dark, London, United Kingdom

e-mail: nina@inthedarkradio.org

(C) The Author(s) 2016

F. Callard et al. (eds.), The Restless Compendium,

DOI 10.1007/978-3-319-45264-7_21
} 
(Nina Garthwaite) had been working for six years. The topics discussed were drawn from Lynne Friedli's research on workfare (work for your benefits schemes) $)^{1}$ and the conversations included: (1) Work for your benefits: is that fair? (2) What's wrong with work? and (3) Is rest possible? We hoped for the kind of conversations that generally don't happen, either in homeless hostels or in academic research, and that would include points of view and experiences that are rarely heard. ${ }^{i}$ The discussions that took place deepened into ongoing dialogue, collaboration and involvement in Hubbub events. This included a Claimants' Day Off - an event for people claiming benefits that provided a day of solidarity and respite from the pressures and penalties faced by 'non-workers'. This chapter features an extract from a conversation between us (Lynne (L) and Nina $(\mathrm{N})$ ), reflecting on our experience of working together, and includes views from residents of the hostel (see Fig. 21.1).

Youknow how manynice, good, clever, intelligent people I met on the street? I never found them in the places I worked.

Rafal Rostovcev, QVSR Resident

I've built so many fucking houses, I can't believe I'm homeless.

Steve Gillman, QVSR Resident

$N$ : The discussions at QVSR weren't originally intended to be part of your research - though now many of the testimonies are. I was wondering what was interesting to you about them from that point of view?

$L$ : They challenged the 'work is good for you' mantra that is the driving force of UK politics and the rhetoric of 'hard working families'. We heard from so many men whose health has been severely affected by poor quality work, who couldn't live on the wages that were available, who have experiences of the worst kind of work and work that doesn't confer dignity, but destroys dignity. Work that leaves you no time or strength to do the things you really want to do. As Stewart said: 'The current working model is failing, mainly because people are treated as slaves ... as part of an economic system that favours making money for business owners'. Or, as others described it: 'sucking everything from you', and 'wage slaves 24/7: working like machines'. Also, there was such unanimous opposition to workfare.

$N$ : Yes, it was frequently described as 'slavery'. Forced unpaid labour.

${ }^{i}$ See also Chap. 18. 
rat people who

obe part of the

Que thing you learn

rictims because of what

lich suggests that

said: "So the

nbusiness'. Yeah,

er people, like you

wite

you

clarify

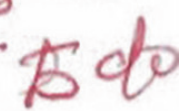

wanl

suppose to working

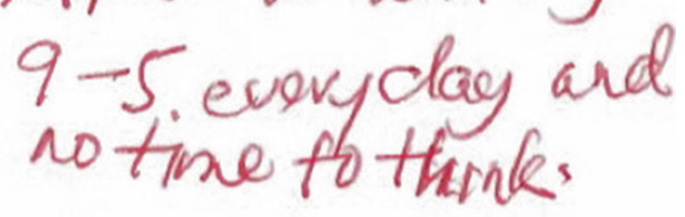

$\longrightarrow$

zounts of what's

to work: 'You

lose your soul, lose

I'.- 7 Goncyr! If

'patronised,

Now

Arae

A

N

G foke

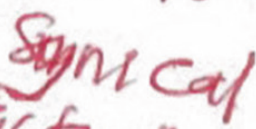

Exe

acfually. Rat was

defig

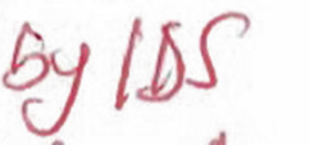

Fig. 21.1 QVSR resident Jon Jonn's feedback on Lynne and Nina's first conversation (Photograph: Nina Garthwaite)

$L$ : Whereas a lot of people who believe their job is secure and are quite cosy in their lives think: 'Why should people get benefits and not work?' They believe themselves to be far removed from insecurity and poverty. But someone like Rafal knows that many people are actually quite close to poverty and homelessness. Like Mick, who's worked from when he was 15 years old, and is now out of work at 65 and can't afford his own place. What I learned from Rafal is how some people hide from their fear of losing everything by despising the people who are closest to that position. 
I think we also heard authentic accounts of what's wrong with work, and why people don't want to work: 'You have to go to work to subsidize the rich'; 'lose your soul, lose your freedom'; 'I don't like being exploited', for example. In fact, Jon mentioned that one of the good things about homelessness is that it gives 'clarity as to what you want to do with your life, as opposed to working nine to five every day and having no time to think' (see Fig. 21.1).

$N$ : Yes, I love that point. Actually, I was struck by the strong sense from a lot of the men that the relationship between money and work was problematic. Stewart said: 'Some people are just good at making huge amounts of money. Not everyone has this capacity - but their work might be vital in other ways.' Steve would say that money makes it impossible for anyone to be free and therefore anyone to rest. I think he understood rest to be being able to truly be yourself, working for love: 'I'd work for love all day long, working for money is nonsense.' I think a lot of the men felt that way. The unanimous agreement from the men was that a decent place to live is fundamental. As Rafal said: 'They [the government] are playing with the top thing, which straight away makes us go down and down, psychologically, and you are completely dependent.'

$L$ : Yes, and rent prices mean even bad work doesn't pay. Mick said, 'I'd be lucky to pull in $£ 11,000$ a year. I couldn't rent privately and feed myself on that'. Now Karim is working, he's looking to leave the hostel and facing huge barriers: 'I just spoke to a landlord who said I had to be three years in work and be earning three times the amount of the rent. They sound like my mother: "Get a job and stick with it!" It's like they're planning my work life!'

$N$ : I think I was surprised by how many people were using a very radical analysis, like Steve's opposition to money, or when he said: 'We're living in a prison, but we can't see the bars so we think we're free. We're not.' Or when Rafal pointed out: 'So the job centre is telling you to "create your own business." Yeah, so you can become a boss and exploit other people, like you were exploited!'

I'd discussed problems with the benefit system with residents before, but never on that kind of systemic level. Residents are rarely consulted about the whole issue of homelessness. Instead, politicians keep handing out solutions from the top down, rather than engaging with people who actually experience the sharp end. It made me think about how QVSR is geared up to help counter individual problems within the frameworks of benefits and charity. As an institution, we rarely reflect on the wider system. Perhaps that means that we are inadvertently expressing support for the current system. I can imagine this can make residents feel even more alone. 
Something else Jon said about this was: 'That's the beauty of the system, you support it by not doing anything about it, but most people here are too tired to keep fighting it. And so they stop, and then they just moan to make themselves feel better. You are too drained to try to make a difference'. It reminds me of something that you talked about once: 'turning complaints into demands'. ${ }^{2}$ When there isn't a context for wider questioning, valid critiques of the system become, or are perceived as, moaning.

L: Well, I was reminded, from listening to the men, how rarely you hear directly from people with an experience of homelessness. When you do hear those stories, they are generally filtered through the big homelessness charities and become part of a version of homelessness circulated by the 'homelessness industry'. You get a very different perspective when you sit down together as we did. What you tend to hear are stories of individual tragedy, whereas what we heard from the men was what is wrong with the system and also, to an extent, how the homelessness industry functions to maintain homelessness.

$N$ : I wonder if, because the debates weren't originally intended to be used for your research, and we didn't really go in with a specific aim, that affected the nature of the conversation?

L: Yes. And I've thought about this again, recently, because Crisis, the big homelessness charity in the United Kingdom, published a report saying that most homeless people agree with sanctions and the idea of 'work for your benefits', ${ }^{3}$ which isn't at all what came out in our discussions. And so I wonder if people respond differently to a survey or professional interview from how they do in what was essentially a conversation with each other? ii $^{\text {Of }}$

Of course, I could have interviewed the residents one to one, but I wonder if it's possible for any researcher to ask a neutral question about benefits. Because to ask someone who is claiming benefits: 'Do you think that people should work for their benefits?' - it's a loaded question. So I think that is why the Crisis report found that the vast majority of the homeless people who were part of their survey said that they did think conditionality was fair, and they did support sanctions. I don't take those findings at face value.

I think you feel so stigmatized when you are claiming benefits that it becomes very difficult to offer a critique of the system to anyone in power - and that includes researchers doing interviews. Jon raised the stigma attached to getting benefits and tax credits very directly when the

${ }^{\text {ii }}$ Cf. Chaps. 7 and 19. 
guys came to a discussion session with Hubbub staff and researchers, and he asked the collaborators: 'Do you think we're lazy?' become more and more entrenched, these issues become more pressing.

And this is also because of the whole industry of 'making money out of unemployed people', whether you are a researcher, or a homelessness charity, or an employment-related support agency. I'm not saying that we avoided all those issues of power in our conversations. I'm not saying that at all. But maybe a debate, a chaired debate, is a more liberating methodology for articulating things that might not be expressed through other forms of inquiry ...

$N$ : Can I ask you something? Your work is research, but you are political too. One member of staff at QVSR read yours and your colleague's article in BMJ Medical Humanities and said he was uncomfortable with what he saw as a political bias in your analysis of workfare. ${ }^{4}$ This is also a general question that has come up in Hubbub research: whether it is $\mathrm{OK}$ for researchers to have a political position. I'm just wondering what your response is to that.

$L$ : I've always made clear that I campaign to end workfare, and so that's an interest I declare. I see my research as a resource for people who are fighting to expose and oppose the psychological coercion that people on benefits experience. My work has a political intention. But in my view, all research is politicaliv: It's just that my research isn't serving the current status quo. I think other researchers and research traditions are equally serving particular ends, but often that's not made explicit.

For me, there's a more uncomfortable question about my research, where I have relied on people's personal accounts. It's a question about who owns people's stories and the way in which, when you take somebody's testimony, which is something that belongs to them, you are taking it and reframing it and you are using it. As a researcher, I am struggling with wanting to ensure that certain voices are heard, and at the same time, not colonizing or appropriating people's stories.

$N$ : I used to work in current affairs documentaries and I felt the same way. I'm still wrangling with it. Mass media narratives are often so un-nuanced that you end up packaging certain people to make them sympathetic, which often means leaving out more complicated realities. You mentioned homeless 'tragedy' stories earlier. Jon spoke about that: 'It's because they make "good stories." Some idiot needs to feel

\footnotetext{
iii See Chap. 22.

iv See Chap. 18.

${ }^{v}$ See Chap. 19.
} 
they felt sorry for you. I don't need it thank you very much. What I need is for you to vote out these idiots, stop building $£ 4$ million flats, start building social houses, stop accepting every shit that is dished out to you and start thinking for yourself'. Well, there's the unfiltered version. But I think that's why we're both reticent to write the debates up as formal findings, and instead want to reflect on an ongoing conversation.

There's also the issue of calling the men 'homeless people'. They were a very mixed group. Mick says: 'Homeless might not mean you've been on the street. I haven't been on the street. I don't call myself homeless because I've got a roof over my head. I think a hostel is a lower grade hotel. I count myself lucky. But then someone might say "I've got a tentthat's shelter - am I homeless?" And in Ilford they found people living in garages.'

$L$ : Homelessness is becoming more common - and routes into homelessness are so varied. Homelessness is such a complex term.

At the same time, shared experiences can be a source of solidarity. As well as grounds for a fierce debate! Of course, all those issues of classification and labelling also came up when we were planning the Claimants' Day Off.

N: I was less involved in the development of the Claimants' Day Off. Could you talk a bit about the thinking behind calling it that?

$L$ : Well, it was a contested issue. 'Claimant' is an imposed identity, and claiming benefits has been deliberately stigmatized by successive governments, and the current government in particular. But it's also a political statement, to come together as claimants. With 2016 being a leap year, 29 February was an extra day, a day we reclaimed from the United Kingdom's Department for Work and Pensions, JobCentrePlus, workfare and the treadmill of 'employability'.

$\mathbf{N}$ : I remember feeling a little nervous putting up the posters at QVSR, in case the men might see it as patronising, but people understood the implicit wink, and found it funny. And of course the day itself, though filled with restful activities, was about more than rest.

L: It meant different things to different people: pleasure, enjoyment of delicious food, solidarity, respite, symbolic resistance. Someone on Twitter described it as 'reclaiming our lives a day at a time'. It was a 'day off'vi together from the relentless psychological pressure of work

${ }^{v i}$ Cf. Chap. 23. 
capability assessments, the threat of sanctions and the compulsion to agree that 'work is good for you'.

$N$ : I know we don't want to impose a unifying narrative on the activities, but I can't help feeling there's something to be said for the central themes of conversation and cake? Food's been important. Do you think cake should play a bigger role in research?

This chapter is dedicated to the memory of Rafal Rostovcev.

Postscript Lynne Friedli, Nina Garthwaite, Karim Addas, Steve Gillman, Mick Hatter, Jon Jonn and Stewart Maxwell presented their work together at the Royal Geographical Society and Institute of British Geographers Annual International Conference in London in the session 'Encounters with Austerity', September 2016.

Acknowledgements We'd like to thank: Residents from Queen Victoria Seamen's Rest who generously contributed their time, knowledge and experiences, including: Steve Gillman, Rafal Rostovcev, Michael Hatter, Bob Tisson, Richard Dawson, Jon Jonn, Abdulkarim Addas, Stewart Maxwell, Martin Mulroe, Emanuel Xerri, Mark Gallagher, William Smith, John Schofield, George Ferrante, John Clarke, Arthur Haskins, John Chapple, Aarne Thompson, Rita Varkalyte and Amal Tukale; everyone who took part in the Claimants' Day Off; and Boycott Workfare.

\section{Notes}

1. Lynne Friedli, and Robert Stearn, 'Positive Affect as Coercive Strategy: Conditionality, Activation and the Role of Psychology in UK Government Workfare Programmes', BMJ Medical Humanities 41, no. I (2015): 40-47.

2. Kathi Weeks, The Problem with Work: Feminism, Marxism, Antiwork Politics, and Postwork Imaginaries (Durham, N.C.: Duke University Press, 2011).

3. Christina Beatty et al., 'Benefit Sanctions and Homelessness: A Scoping Report' (London: Crisis/Sheffield Hallam University Centre for Regional, Economic and Social Research, March 2015), http://www.crisis.org.uk/ data/files/publications/Sanctions\%20Report\%202015_FINAL.pdf.

4. Friedli and Stearn, 'Positive Affect as Coercive Strategy'. 


\section{Further Resources}

Boycott Workfare (UK-wide campaign to end forced unpaid work for people who receive welfare). www.boycottworkfare.org.

Well Red Films. And This Time It's Personal: Psycho-Compulsion and Workfare. Well Red Films, 2016. https://vimeo.com/157125824.

Lynne Friedli is a freelance researcher, with a special interest in mental health and social justice. She wrote 'Mental Health, Resilience and Inequalities' for World Health Organization Europe, and is currently researching the (mis)use of psychology in workfare and other employment programmes.

Nina Garthwaite is Director of In The Dark, an audio arts organization. Over the last six years, she has commissioned new works from producers around the world and staged countless live listening events at festivals, theatres, cinemas and museums.

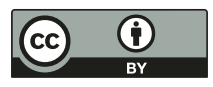

This chapter is distributed under the terms of the Creative Commons Attribution 4.0 International License (http://creativecommons.org/ licenses $/$ by $/ 4.0 /$ ), which permits use, duplication, adaptation, distribution and reproduction in any medium or format, as long as you give appropriate credit to the original author(s) and the source, a link is provided to the Creative Commons license and any changes made are indicated.

The images or other third party material in this chapter are included in the work's Creative Commons license, unless indicated otherwise in the credit line; if such material is not included in the work's Creative Commons license and the respective action is not permitted by statutory regulation, users will need to obtain permission from the license holder to duplicate, adapt or reproduce the material. 